\title{
New Prospect for Improving University Students' Quality of Life
}

Authors' contribution:

A) conception and design of the study

B) acquisition of data

C) analysis and interpretation of data

D) manuscript preparation

E) obtaining funding

\section{László Edvy}

Pannon University, Hungary

\begin{abstract}
It is well-known that the poor exercise habits characterizing modern civilization are a high risk factor in health. Countervailing them is the responsibility of all social subsystems. This study aims to observe the role of higher education within the framework of comprehensive research carried out at the University of Pannonia, Hungary. A course meeting university standards has been developed for students, the future opinion-shapers, which intends to strengthen the health consciousness, the basis of physical fitness. The objective of the article is to prove the effectiveness of the course and its impact on lifestyle through a longitudinal study. Accordingly, it aims to answer the following questions: Can a change be observed in the factors of students' psychological and health-related quality of life? Does the health consciousness developed by the course result in a more efficient health-enhancing physical activity? Does broadening knowledge provide long-term motivation for maintaining an active lifestyle? The efficiency of the course has been evaluated through changes observed in the participating students' quality of life and health consciousness using the following methods: survey $(\mathrm{N}=479)$, in-depth interview $(\mathrm{N}=86)$, and triangulation. The results of the study support the basic assumption that the knowledge acquired in the course contributes in the short run to the students planning their health-preserving life-coaching more consciously, while quality of life indicators change in the long run. Consequently, it has been determined that the transmission of knowledge through the course is an undertakeable and successful endeavor of higher education in the field of health education.
\end{abstract}

health education, health promotion, higher education, fitness, quality of life

\section{Introduction}

The 1996 issue of the $\mathrm{CDC}^{1}$ drew the world's attention to the health risks that are caused by a drastic decrease in habitual physical activity (CDC, 1996). There have been numerous attempts by nations at the governmental level to step up against these negative tendencies (U.S., 2000; Australia, 1988; England, 1986; Denmark, 1993; Magyarország, 2003). This has not been a smashing success, as further monitoring studies have proven (Bruce, 2002; Jaret, 2000). However, physical activity based on conscious planning, aiming at

\footnotetext{
${ }^{1} \mathrm{CDC}$ : The Centers for Disease Control and Prevention, the US agency charged with tracking and investigating public health trends.
} 
promoting founding health, i.e., health-enhancing physical activity (HEPA) (WHO, 2007), can only become a practice of general scope in a society whose upcoming generations consider it natural rather than mandatory (Jakó, 2012).

In Hungary, the quotidian P.E. classes introduced by the 2013 amendment about national public education may provide the upcoming generation with a chance for an individual-driven quality of life. But what happens to the generations unable to disengage from "miscoded" inactivity? The possible roles of social subsystems need to be re-evaluated.

Based on national research, the most effective channels for introducing regular physical activity with preventive purposes are consultations held by physicians or other specialists, and scientifically well-founded brochures (Fuscaldo, 2002). Higher education may prove to be a possible institutional background for this.

At the University of Pannonia, comprehensive research has been initiated to explore students' quality of life and optimize their life-coaching. The social subsystem in focus demands particular attention because, with time, it will become the opinion-shaping model of society (Frenkl, 1997).

In the first phase of research, the students' health-related indicators of quality of life were investigated along the dimensions of Hungarostudy 2002, a representative study about the Hungarian population's quality of life (Kopp \& Kovács, 2006). It was concluded that by the factors of quality of life taken into account, the sector of society that we observed does not possess the expected level necessary for healthy life-coaching (Edvy, 2013a). This reflects the results of the national survey which compared the psychological quality of life of students from Western Europe and those from Central Europe, indicating the disadvantage of the students in our region (Wardle et al., 2004). All of this further supports the need for higher education to take part in compensating for the risks put forth by the CDC.

Our examinations have outlined well-definable areas of students' quality of life. The role of psychosomatic factors has already been proven (Mikolajczyk et al., 2008). Health-preserving life-coaching, which is suitable for enhancing the above-mentioned factors (Craft, 2006; Morgan, 1985), has proven to be a decisive constituent in determining the target group's quality of life. Improving it is a task undertakeable by higher education as this process can be well-integrated into its system (Edvy, 2012).

Upon verifying the necessity and possibilities of its role in the improvement of health at the university level, the second phase of the study was launched. A course was developed to propagate health-preserving life-coaching, including knowledge about HEPA. The result of a 4-year study (Lewin, 1946) was an accessible and popular subject involving theoretical and practical training (Edvy, 2013b).

\section{Objectives and hypotheses}

The course developed at the University of Pannonia is intended to serve as a model for health improvement. For this to be generally accepted, it is essential to scientifically support the effectiveness of the course, which is the third phase of our research. Accordingly, this article attempts to prove the following hypotheses:

1. Considerable change in psychological and health-related factors of quality of life is not expected to be observed during the short time-span of the course. Only a positive shift is assumed to occur. A more significant improvement is expected in health-preventing life-coaching: according to our assumptions, the fulfillment of fitness goals results from conscious planning.

2. It is assumed that by improving students' related knowledge, students can conceive their level of health and fitness more realistically, which proves to be a long-term motivation for maintaining conscious, health-preserving life-coaching.

3. Finally, it is assumed that the course is not the only source that is a decisive factor in the prognosticated improvement. 


\section{Method}

Sample

The population for the complex research was given by students of the University of Pannonia (479 people). The number of students participating in the course, thus providing the basis for proving its effectiveness, was 86 .

Before introducing the methodology of the course, it must be noted that the indicators of quality of life for the 86 students as established before the course, and the level of applicability of their health consciousness, did not considerably differ from those of the fundamental research. Therefore, it is justified to train groups "spontaneously" organized for a semester. This is supported by the result of the variance analysis for comparison of independent samples (ANOVA).

Twenty-four students, $27.9 \%$ of the course participants, could be involved in the interviews investigating the long-term effects of the course. The group was collected by random sampling, and its relationship to the population was also evaluated through variance analysis. At each parameter, the level of the significance of divergence exceeded the 0.05 threshold. Therefore, it can be concluded that there is no significant divergence between the two samples; they can be considered homogenous.

\section{Analysis of the differences in students' quality of life and the health-preserving life-coaching influencing it}

The structured questionnaire applied in the fundamental research included the following groups of questions:

- Analysis of psychological indicators of quality of life (WHO General Well-Being Index (Beck et al., 1996), abridged Beck Depression Inventory [Beck \& Beck, 1972], abridged Vital Exhaustion Questionnaire (Kopp et al., 1998), abridged Hopelessness Scale (Beck et al., 1974));

- Analysis of health-related indicators of quality of life (Self-assessment of general health [Idler \& Benyamini, 1997], Restrictive effect of sensation of pain (Martin et al., 1987), Days of sickness (Kopp \& Kovács, 2006), Burden of disease index (Devis et al., 1983));

- Analysis of health-preserving life-coaching (health consciousness, consciousness of planning fitness); The detailed description of the complex variables entitled "health consciousness" and "conscious fitness" is necessary for comprehending the results of the analysis. Questions assessing health consciousness evaluated subjects' ability to identify kilter-factors (training frequency, endurance, strength, flexibility) and their assessment. Questions about conscious improvement of physical fitness investigated subjects' understanding of the physiological effects of exercise and whether or not they are planned. In both cases, data-processing was facilitated by a 5-level Litkert scale. Conditional abilities acquired by applied exercises were evaluated by an open-ended question. Answers were categorized (1-endurance, 2-strength, 3-full coverage of abilities). The change in criteria of selecting elements and forms of physical activity was investigated through a 10-item closed-ended multiple-choice group of questions. Possible aspects: type of sport, time-span, intensity, fitness, health-related necessity, expected physical effect, location, weather-sensitivity. The number of chosen aspects was fixed at the evaluation; accordingly, the maximum value available was 10 .

The above-introduced questionnaire analysis was completed by the students of the course at the beginning of the semester and also at the end as a control. The repeated evaluation provides an opportunity for registering changes in certain factors. 


\section{Perception of the course by students}

One of the feedback methods of the study aiming to improve the course was a questionnaire about students' satisfaction (Edvy, 2013b). It intended to investigate the effects of the course on individual motivation, realistic self-assessment of condition, and the executability of the fitness program. The dataprocessing was facilitated by using a 5-level Litkert scale (1 - not at all, 5 - absolutely).

\section{Understanding the long-term effects of the course}

Further analysis was needed to prove that the registered changes were indeed a result of the course. The validity of the result of our primary qualitative study is amplified through methodological triangulation (Szabolcs, 2001). Accordingly, deeper connections, the actual origins of the expected expansion of knowledge and the long-term effects of the conveyed ideas, were intended to be explored via in-depth interview.

\section{Statistical analyses}

The probability of changes in the students' quality of life during the course was analyzed through variance analysis (one-way ANOVA) in case of data interpreted on interval-scale, while chi-square test was used with nominal data. Besides a descriptive statistical analysis, it also seemed necessary to apply correlation, partial correlation, and factor-analysis to prove the effectiveness of the course. In the case of interviews, a homogeneity-test was posteriorly used to verify that the group of interviewees and students did not show divergence along the main characteristics observed in our study. For statistical analyses, SPSS 18.0 version was used (SPSS Inc., Chicago, IL, USA).

\section{Results}

Comparison of the level of health-related quality of life and health consciousness before and after the course

The means of indicators of psychology- and health-related quality of life show a positive shift. The level of significance of change, however, has not once exceeded the threshold expected in pedagogical research ( $\mathrm{p}<0.05)$. Yet, steady improvement can be forecast in health consciousness, conscious planning of fitness, and aspects considered when practicing sports (Table 1).

Table 1. Variance analysis (one-way ANOVA) for exploring changes of areas improved by the course

\begin{tabular}{|c|c|c|c|c|c|c|}
\hline & & $\begin{array}{c}\text { Sum of } \\
\text { Squares }\end{array}$ & df & $\begin{array}{c}\text { Mean } \\
\text { Square }\end{array}$ & $\mathbf{F}$ & Sig. \\
\hline \multirow{3}{*}{ Health consciousness } & Between Groups & 139.680 & 1 & 139.680 & 18.075 & 0.000 \\
\hline & Within Groups & 1313.733 & 170 & 7.728 & & \\
\hline & Total & 1453.413 & 171 & & & \\
\hline \multirow{3}{*}{ Aspects of sports } & Between Groups & 45.023 & 1 & 45.023 & 15.744 & 0.000 \\
\hline & Within Groups & 486.140 & 170 & 2.860 & & \\
\hline & Total & 531.163 & 171 & & & \\
\hline \multirow{3}{*}{ Conscious fitness } & Between Groups & 168.023 & 1 & 168.023 & 24.106 & 0.000 \\
\hline & Within Groups & 1184.953 & 170 & 6.970 & & \\
\hline & Total & 1352.977 & 171 & & & \\
\hline
\end{tabular}

The results of analyzing health consciousness show that before the course, students attached special importance to regular exercise and endurance, while the impact of strength and flexibility on health was way underestimated. 
The statistical analysis presented in Table 2 proves the successful value-transmission: the rating of strength and flexibility has intensified, while health-focused judgments of physical abilities have become more balanced.

Table 2. Variance analysis (one-way ANOVA) for exploring changes in health consciousness (identifying kilter-related factors)

\begin{tabular}{|c|c|c|c|c|c|c|}
\hline & & $\begin{array}{c}\text { Sum of } \\
\text { Squares }\end{array}$ & df & $\begin{array}{c}\text { Mean } \\
\text { Square }\end{array}$ & $\mathbf{F}$ & Sig. \\
\hline \multirow{3}{*}{$\begin{array}{l}\text { Regular exercise ( } 2 \text { times/ } \\
\text { week) }\end{array}$} & Between Groups & 2.814 & 1 & 2.814 & 9.393 & 0.003 \\
\hline & Within Groups & 50.930 & 170 & 0.300 & & \\
\hline & Total & 53.744 & 171 & & & \\
\hline \multirow{3}{*}{ Endurance } & Between Groups & 4.238 & 1 & 4.238 & 10.682 & 0.001 \\
\hline & Within Groups & 67.453 & 170 & 0.397 & & \\
\hline & Total & 71.692 & 171 & & & \\
\hline \multirow{3}{*}{ Strength } & Between Groups & 7.535 & 1 & 7.535 & 11.347 & 0.001 \\
\hline & Within Groups & 112.884 & 170 & 0.664 & & \\
\hline & Total & 120.419 & 171 & & & \\
\hline \multirow{3}{*}{ Flexibility } & Between Groups & 17.587 & 1 & 17.587 & 20.302 & 0.000 \\
\hline & Within Groups & 147.267 & 170 & 0.866 & & \\
\hline & Total & 164.855 & 171 & & & \\
\hline
\end{tabular}

According to the results of the questionnaire examining the consciousness of improving physical fitness, knowledge before the course was weakest about the physiological effects of strain (mean: 3.42). While $65.1 \%$ of the students considered their chosen form of exercise to be planned with respect to target fitness, $77.8 \%$ was hardly aware or was not aware of its effects on the body. Upon completing the course (Table 3), knowledge about physiological effects improved the most significantly.

Table 3. Variance analysis (one-way ANOVA) for exploring changes in consciousness of improving fitness

\begin{tabular}{|c|c|c|c|c|c|c|}
\hline & & $\begin{array}{l}\text { Sum of } \\
\text { Squares }\end{array}$ & df & $\begin{array}{l}\text { Mean } \\
\text { Square }\end{array}$ & $\mathbf{F}$ & Sig. \\
\hline \multirow{3}{*}{ Fatigue during exercise } & Between Groups & 2.814 & 1 & 2.814 & 4.410 & 0.037 \\
\hline & Within Groups & 108.465 & 170 & 0.638 & & \\
\hline & Total & 111.279 & 171 & & & \\
\hline \multirow{3}{*}{ Exercise being gratifying } & Between Groups & 0.145 & 1 & 0.145 & 0.610 & 0.436 \\
\hline & Within Groups & 40.523 & 170 & 0.238 & & \\
\hline & Total & 40.669 & 171 & & & \\
\hline \multirow{3}{*}{$\begin{array}{l}\text { Exercise based on target } \\
\text { fitness }\end{array}$} & Between Groups & 5.953 & 1 & 5.953 & 5.828 & 0.017 \\
\hline & Within Groups & 173.674 & 170 & 1.022 & & \\
\hline & Total & 179.628 & 171 & & & \\
\hline \multirow{3}{*}{$\begin{array}{l}\text { Awareness of extent of } \\
\text { fatigue resulting from } \\
\text { exercise }\end{array}$} & Between Groups & 8.843 & 1 & 8.843 & 8.266 & 0.005 \\
\hline & Within Groups & 181.872 & 170 & 1.070 & & \\
\hline & Total & 190.715 & 171 & & & \\
\hline \multirow{3}{*}{$\begin{array}{l}\text { Awareness of } \\
\text { physiological effect of } \\
\text { exercise }\end{array}$} & Between Groups & 39.093 & 1 & 39.093 & 42.870 & 0.000 \\
\hline & Within Groups & 155.023 & 170 & 0.912 & & \\
\hline & Total & 194.116 & 171 & & & \\
\hline
\end{tabular}

In analyzing the correlation between the relevant variables (factor analysis), the highest factor-loading (0.835) is assigned to knowledge about physiological effects. 
Altogether, the result of the dissimilarity-analysis shows that an expansion of knowledge in the improvement of fitness can be prognosticated by the end of the course. Only the subjective evaluation of the exercise ("Is the exercise gratifying?") lacks significant divergence.

By the end of the course, exercises chosen by the students presented higher coverage of the conditional abilities than at the beginning (Table 4). The probability of changes was measured by the chisquare test for nominal data $\left(\chi^{2}=20.934 ; \mathrm{p}=0.000\right)$. It can be concluded that well-proportioned abilitydevelopment is highly predictable by the end of the course.

Table 4. Cross-table analysis of conditional abilities improvable via sports practiced by the students

\begin{tabular}{|c|c|c|c|c|}
\hline \multicolumn{5}{|l|}{ Count } \\
\hline & & \multicolumn{2}{|c|}{$\begin{array}{l}\text { Before course - after } \\
\text { course }\end{array}$} & \multirow[t]{2}{*}{ Total } \\
\hline & & 1 & 2 & \\
\hline \multirow{3}{*}{ Conditional ability improved via exercise } & endurance & 32 & 15 & 47 \\
\hline & strength & 11 & 1 & 12 \\
\hline & mixed & 43 & 70 & 113 \\
\hline Total & & 86 & 86 & 172 \\
\hline
\end{tabular}

At the end of the course, changes were registered in the number of aspects in choosing elements of physical activity. Initially, the mean-value of choosing from the listed parameters was 5.56. However, as a result of increased knowledge, it increased to 6.58 by the end of the course. This change is unequivocally supported by the result of the variance analysis $(\mathrm{F}=15.744 ; \mathrm{p}=0.000)$.

For the dissimilarity-analysis based on certain aspects, the chi-square test was used again in accordance with nominal variables. Based on this, the range of criteria was proven to be supported by the individual's kilter $\left(\chi^{2}=3.839 ; \mathrm{p}=0.050\right)$, health-related necessity $\left(\chi^{2}=7.966 ; \mathrm{p}=0.005\right)$, expected physical effect $\left(\chi^{2}=5.983 ; p=0.014\right)$, front-effect $\left(\chi^{2}=8.881 ; p=0.003\right)$, and weather-sensitivity $\left(\chi^{2}=6.525 ; \mathrm{p}=0.011\right)$.

\section{Evaluation of students' opinion of the course via control-questionnaire}

The control-questionnaire was intended to elicit the direct effects as experienced by the students (Table 5). The kilter-evaluation, based on a comprehensive fitness test, resulted in $73.3 \%$ of the students changing their views on fitness significantly, and $86.1 \%$ claiming increasing resolve towards improving their kilter. As a consequence of this expansion of knowledge, $73.2 \%$ of the students needed to re-evaluate their previous target fitness considerably. Almost all of the students, at $96.5 \%$, claimed that the acquired knowledge would help them reach their aims, and $98.9 \%$ found the course suitable for conveying knowledge about improving fitness.

Table 5. Descriptive statistical analysis of student satisfaction

\begin{tabular}{|c|c|c|c|c|c|c|c|c|}
\hline & $\mathbf{N}$ & Range & Min. & Max. & \multicolumn{2}{|c|}{ Mean } & \multirow{2}{*}{$\begin{array}{c}\begin{array}{c}\text { Std. } \\
\text { Deviation }\end{array} \\
\text { Statistic }\end{array}$} & \multirow{2}{*}{$\begin{array}{l}\text { Variance } \\
\text { Statistic }\end{array}$} \\
\hline & Statistic & Statistic & Statistic & Statistic & Statistic & $\begin{array}{l}\text { Std. } \\
\text { Error }\end{array}$ & & \\
\hline $\begin{array}{l}\text { Has student's view of } \\
\text { his/her own fitness } \\
\text { changed? }\end{array}$ & 86 & 4 & 1 & 5 & 3.78 & 0.122 & 1.131 & 1.280 \\
\hline $\begin{array}{l}\text { Has student become } \\
\text { more motivated in } \\
\text { improving his/her own } \\
\text { fitness? }\end{array}$ & 86 & 4 & 1 & 5 & 4.34 & 0.094 & 0.876 & 0.767 \\
\hline $\begin{array}{l}\text { Did the course transmit } \\
\text { new information? }\end{array}$ & 86 & 4 & 1 & 5 & 4.74 & 0.067 & 0.617 & 0.381 \\
\hline
\end{tabular}




\begin{tabular}{|c|c|c|c|c|c|c|c|c|}
\hline $\begin{array}{l}\text { Need for re-evaluation } \\
\text { of target fitness based } \\
\text { on acquired knowledge? }\end{array}$ & 86 & 4 & 1 & 5 & 3.91 & 0.112 & 1.036 & 1.074 \\
\hline $\begin{array}{l}\text { Information helping } \\
\text { student realize target } \\
\text { fitness? }\end{array}$ & 86 & 4 & 1 & 5 & 4.72 & 0.071 & 0.662 & 0.439 \\
\hline $\begin{array}{l}\text { Course suitable for } \\
\text { conveying knowledge } \\
\text { about fitness? }\end{array}$ & 86 & 4 & 1 & 5 & 4.81 & 0.059 & 0.543 & 0.294 \\
\hline Valid N (list-wise) & 86 & & & & & & & \\
\hline
\end{tabular}

There is a positive and significant correlation between the acquisition of new knowledge and change in the evaluation of kilter $(\mathrm{r}=0.272 ; \mathrm{p}=0.011)$. Excluding motivation, however, the partial correlation coefficient does not show a proven correlation $(\mathrm{r}=0.035 ; \mathrm{p}=0.751)$, while motivation does have a significant correlation with both variables $(\mathrm{p}=0.000)$.

The significant effect of motivation can be observed in the relationship between acquired knowledge and a realistic fitness target as well, but the relationship between the two variables $(r=0.404 ; p=0.000)$ is not correlated when eliminating motivation $(\mathrm{r}=0.210 ; \mathrm{p}=0.053)$.

\section{Evaluation of the long-term effects of the course}

The partly-structured interview focuses on four topics: changes in life-coaching, health consciousness, and motivation, and the overall effects of the course. The results are as follows:

A significant number of interviewees, 91.7\%, reported changes in their life-coaching, mainly in the form of more regular and consciously-planned physical exercise. Two-thirds used the workout routine prepared as a course requirement in accordance with their kilter and target fitness. All of them, except for two, considered the acquired knowledge useful for implementing their plan, possibly with the help of their notes, academic literature, or even the faculty of the university.

Also, 91.7\% experienced improvement in their health consciousness, and $79.1 \%$ attributed it to the course. For those who already had a healthy lifestyle, the course served as a guideline and had a reassuring and systematizing effect.

All of the interviewees claimed that they had become more motivated in realizing a healthier, more active lifestyle. The improvement of quality of life was the strongest incentive for $33.3 \%$ of them. Further, one-third felt it was a success to have the knowledge to plan tailor-made exercise guaranteeing efficiency. Overcoming what they initially perceived to be their individual limits and contention also provided them with motivation.

The final question of the interview intended to elicit the course's overall effect on the students. Most claimed that through trustworthy professionals, the course provided a great basis for successfully developing individual health-enhancing physical activity.

\section{Discussion and conclusion}

The course developed at the University of Pannonia for enhancing health consciousness seems to have, through continuous feedback, reached the stage of an efficient conveyance of knowledge. The course is offered every semester separately for male and female students, in order to adjust for gender differences (Herman et al., 2011). It is an optional course with 2 hours of theory and 2 hours of practice.

Professionalism, that is, guaranteeing efficiency, is essential. Therefore, the process of conveying knowledge follows the professional protocol in which a personal trainer introduces regular exercise to an individual with an inactive lifestyle while assuring success (Zopcsák, 2010). Students' attainment of knowledge can be considered efficient in light of the results, which is proven by the syllabus. 
The review of positive physiological effects of regular exercise is based on systemizing knowledge that students previously acquired in high school. In order to awaken interest and motivation, it is imperative that students not regard the average references currently characteristic of the population as a basis for evaluating his or kilter. Instead, he or she should take the normal condition characteristic of the actual phase of individual improvement as a reference (Bíróné, 2004, pp. 101-103). This is why students take their own fitness test at the beginning of the course. It considerably changes their judgment about the environment and their own state of health. This puts forth a realistic fitness target, based on real demands. However, in order to realize it, a further expansion of health consciousness is necessary. Before learning about improving motor abilities, students learn about their physiological connections, thus eliminating a lack of knowledge about the physiological background of different forms of exercise and the relationship between the differentiated adaptation processes resulting from them. A theoretical introduction of exercise equipment is followed by practice, thereby ingraining their effect and target-system. After acquiring the algorhythm of periodization and the principles facilitating the planning of regular exercise, students are required to prepare their own tailor-made fitness workout routine, with the possibility of personal consultations.

The course did not yield a detectable change in students' attitude regarding practices with harmful effects on health. The training deficit in the area of smoking and healthy nourishment can be explained by two factors. one is objective, i.e., the course does not cover this topic in depth; second, different attitudes towards health suggest different kinds of motivation (Adams \& White, 2005). This is the basis of the lifestyle-model of different motivations. Thus, a need remains for the content of the course to be expanded.

A significant claim of positive student feedback was that motivation resulting from increased knowledge generates the change leading to improved kilter. Accordingly, the instructor's credibility and setting of example are also conditions and expectations of an efficient course.

The expansion of knowledge through the course is evident, and the information conveyed by the course plays a crucial role in it. Still, health-preserving life-coaching as put into practice cannot show significant changes in quality of life by the end of a course; it takes more time. The monitoring study, on the other hand, proves that the conveyed knowledge has an impact on the individual's life-coaching, occasionally resulting in a complete lifestyle change.

Altogether, our hypotheses have been supported.

This course proves that the role of higher education in the improvement of health is an opportunity as well as a responsibility. Health-preserving life-coaching, especially HEPA, has proven to be an undertakeable segment of health-education, and also a determining factor in a target group's quality of life (Edvy, 2012). The following citation from an interview is intended to demonstrate the chance that has been given to our students through the transmitted knowledge:

"It has brought a substantial change into my life (...) it has changed my view about me and my physical limits incredibly (...) The love of exercise has become so ingrained in my life that I actually have an effect on my environment in that respect".

I consider it necessary to re-evaluate the role of higher education in the promotion of health through further studies on this topic. I recommend that institutes prepare their strategies in connection with the promotion of their students' health on the basis of these research findings.

\section{REFERENCES}

Adams, J. \& White, M. (2005). Why don't stage-based activity promotion interventions work? Health Education Research, 20, 237-243.

Australia (1988). Health Targets and Implementation Committee. Health for all Australians. Canberra: Australian Government Printing Service. 
Bech, P., Staehr-Johansen, K. \& Gudex, C. (1996). WHO (Ten) Well-Being Index: Validation in diabetes. Psychotherapy and Psychosomatics Journal, 65, 183-190.

Beck, A.T., Weissman, A., Lester, D., Trexler, L. (1974). The measurement of pessimism: The Hopelessness Scal. Journal of Consulting and Clinical Psychology, 42, 861-865.

Beck. A.T. \& Beck, RW. (1972). Sortend version of BDI. Postgraduate Medical Journal, 52, 81-85.

Bíróné, N.E. (2004). Sportpedagógia [Sport pedagogy]. Budapest-Pécs: Dialóg Campus Kiadó. 101-103.

Bruce, M.J. \& Kattzmarzyk, PT. (2002). Canadian population trends in leisure-time physical levels, 1981-1998. Canadian Journal of Applied Physiology, 27(6), 681-690.

CDC. (1996). Physical Activity and Health: A Report of the Surgeon General. Retrieved May 10, 2014, from http://www.cdc.gov/nccdphp/sgr/pdf/sgrfull.pdf.

Craft, L.L. (2006). Exercise and clinical depression: examining two psychological mechanisms. Psychology of Sport and Exercise, (6), 151-171.

Denmark (1993). World Health Organization/Europe. Health for all targets. The health policy for Europe. Denmark: WHO Regional Office for Europe;

Devis, G.M., Binik, Y.M., Hutchinson, T.A., et al. (1983). The emotional impact of end-stage renal disease: Importance of patient's perceptions of intrusiveness and control. International Journal of Psychiatry in Medicine, 13, $327-343$.

Edvy, L. (2012). A Pannon Egyetem hallgatóinak fittségét megalapozó egészségtudata és az egészséggel kapcsolatos életminőség mutatói /The indicators of health in relation of life quality of students at Pannon University, in connection with basing the fitness of the health consciousness/. Hungarian Review of Sport Science, 49, 4-10.

Edvy, L. (2013a). Quality of Life Indicators of University Students in Hungary. Physical Culture and Sport. Studies and Research, 58(1), 53-60.

Edvy, L. (2013b). Egészségtudatot formáló kurzus megalapozása és fejlesztése a Pannon Egyetemen /The foundation and development of course for health consciousness at Pannon University/. Hungarian Review of Sport Science, 53, 2529.

England (1986). Department of Health. The Health of the Nation. A strategy for health in England. Cm. 1986. London: HMSO; 1992

Frenkl, R. (1997). Az urbanizáció kihívása /The challenge of urbanization/. In Aszmann, A., Frenkl, R., Kaposvári, A., et al., Felsőoktatás értelmiség egészsége /The health of intellectuals at higher education/. (pp. 5-14). Budapest: Magyar Egyetemi-Főiskolai Sportszövetség.

Fuscaldo, J.M. (2002). Prescribing physical activity in primary care. West Virginia Medical Journal, 98(6), 250-3.

Herman, K.M., Hopman, W.M. \& Craig, C.L. (2011). Sex differences in the association of youth body mass index to adult health-related quality of life: the physical activity longitudinal study. Canadian Journal of Public Health, 102(1), 42-6.

Idler, E.L. \& Benyamini, Y. (1997). Self-rated health and mortality: A review of twenty-seven community studies. Journal of Health and Social Behavior, 38, 21-37.

Jakó, P. (2012). Sport, egészség, társadalom /Sport, health, society/. Acta Chimica Academiae Scientiarum Hungaricae, 173, 1081-1090.

Jaret, P. (2002). Healthy People 2000: Helping Patients Change. Hippocrates. 14(1), 25-30.

Kopp, M. \& Kovács, M. (2006). A magyar népesség életminősége az ezredfordulón [Quality of life in Hungarian population at the millennium]. Budapest: Semmelweis Kiadó.

Kopp. M., Falger, P., Appels, A., et al. (1998). Depressive symptomatology and Vital Exhaustion are differentially related to behavioural risk factors for coronary artery disease. Psychosomatic Medicine, 60, 752-758.

Lewin, K. (1946). Action research and minority problems. Journal of Social Issues, 2(4), 46.

Magyarország (2003). Országgyülési határozat. Az egészség évtizedének népegészségügyi programja. /Parliamentary decision. National program for the decade of health/. Budapest, Magyarország: 46/2003. (IV. 16.) OGY határozat;

Martin, J., Bone, M. \& Melteer, H. (1987). OPCS surveys of disabled people Great Britain. London: OPCS.

Mikolajczyk, R., Brzoska, P., Maier, C., et al. (2008). Factors associated with self-rated health status in university students; a cross-sectional study in three European countries. BMC Public Health, 8, 215.

Morgan, WP. (1985). Affective beneficence of vigorous physical activity. Medicine and Science in Sports and Exercise, (17), 94-100.

Szabolcs, É. (2001). Kvalitatív kutatási metodológia a pedagógiában /Qualitative research methodology in pedagogy/. Budapest: Müszaki Könyvkiadó. 
U.S. (2000). Healthy People 2010. Understanding and Improving Health. Department of Health and Human Services November 2000. Retrieved May 10, 2014, from http://www. healthypeople.gov/2010/document/pdf/uih/2010uih.pdf?visit=1.

Wardle, J., Steptoe, A., Gulis, G., et al. (2004). Depression, perceived control, and life satisfaction in university students from Central-Eastern and Western Europe. International Journal of Behavioral Medicine, 11(1), 27-36.

WHO (2007). World Health Organization. Steps to Health. A European Framework to Promote Physical Activity For Health. Copenhagen, Denmark: WHO Regional Office for Europe.

Zopcsák, L. (2010). Személyi edző képzés tanfolyami jegyzet /Textbook for Personal Trainer Course/. Budapest: International Wellness Institute.

AUTHOR'S ADDRESS: $\quad$ László Edvy

Institute of Physical Education and Sport

Pannon University

Egyetem utca 10

8200 Veszprém, Hungary

Email: edvyl@almos.vein.hu 